\title{
Digital technologies in the industry: application of immersive training technologies in the oil and gas complex
}

\author{
Anna Smirnova ${ }^{1}$, Irina Zaychenko ${ }^{1, *}$, Irina Bagaeva ${ }^{1}$ and Polina Gorshechnikova ${ }^{1}$ \\ ${ }^{1}$ Peter the Great St. Petersburg Polytechnic University, 195251, 29 Polytehnicheskaya st., Russia \\ ${ }^{2}$ Candidate of History, assistant, Department of History, Saint Petersburg Mining University, 199106, 2, 21st Line, St Petersburg, Russia
}

\begin{abstract}
The article substantiates the need to apply training and retraining programs for personnel for permanent work in the Arctic using digital technologies, namely VR / AR / MR technologies. The geopolitical features of the Arctic zone, difficult climatic conditions do not allow directly practicing the development of professional competencies and, therefore, require the introduction of a multi-stage system of personnel training using technologies of approximate reality. Such requirements for the personnel training system predetermine the need to search for relevant digital technologies that can create conditions that are as close as possible to the conditions of professional activity in hard-to-reach Arctic regions. When forming a personnel training / retraining system for oil and gas enterprises, in addition to the specified specific working conditions, it is also necessary to take into account the sectoral features of oil and gas enterprises, which also forms a number of functional requirements for the selection of relevant digital tools, the main of which for personnel training can be considered immersive technologies. Based on the above, the paper analyzes the use of immersive technologies by oil and gas enterprises, a comparative analysis of the directions of using immersive technologies in personnel training at oil and gas enterprises, identifies the positive and negative aspects of using VR / MR / AR technologies.
\end{abstract}

\section{Introduction}

The urgency of solving the issues of training and retraining of personnel for these regions is explained by the acceleration of the development of the Arctic territories. According to the monitoring data of the Ministry of Education and Science of the Russian Federation [1], the need for personnel is 25 thousand people annually. Strengthening the research activities of educational institutions in the field of solving problems of the development and development of the Arctic region is also recognized as a very urgent issue. Currently, Arctic programs are being implemented in thirty educational organizations, six of which are located in the Arctic zone of the Russian Federation. As a result, by 2024 an education system will be built that will be consistent at all levels, and it will also include the identification and support of talents in the fields of mathematics and computer science, the training of highly qualified personnel who will fulfill the new requirements for key competencies of the digital economy, the implementation of programs retraining for professions in demand in the digital economy, as well as promising educational projects. However, at present, a huge number of highly qualified personnel are employed in the Arctic territories, and their additional education outside of production will not be profitable for many enterprises. That is why the development of training programs for personnel, including those aimed at acquiring digital competencies on the job, is a paramount task in the development of the Arctic spaces.

Thus, the new socio-economic and technological conditions for the development of these territories require the development and implementation of new conceptual approaches to the formation of training programs for personnel, including adaptation programs that are aimed at obtaining employees of key competencies of the digital economy.

The aim of the work is to analyze the possibilities of using digital technologies in the development of on-thejob training programs for personnel in the oil and gas complex.

Work tasks: analysis of the use of digital technologies in the development of training programs and retraining of personnel; identification of relevant technologies for personnel training for oil and gas enterprises located in remote areas; identification of positive and negative aspects of using digital technologies in training personnel at oil and gas enterprises.

\section{Existing Literature}

Currently, there is a huge number of works in the scientific literature that are devoted to the analysis of digital technologies in the digital transformation of business [2-9]. Nevertheless, most of the works are of a general nature and do not take into account either the

* Corresponding author: imz.fem.spbpu@mail.ru 
sectoral or climatic characteristics of production. A large number of works are devoted to the development and management of the socio-economic development of the Arctic territories [10-15].

There is a number of analytical studies of manufacturing companies on the implementation of digital technologies [16-25], but at the same time, the reports do not pay attention to the issues of personnel training using digital technologies, most of the reviewed reports contain information on the use of IoT, big data, artificial intelligence and digital twins ...

Currently, in the context of the development of the digital economy, an increase in the level of production, including in the oil and gas industry, is possible, among other things, through the introduction of immersive technologies into the production process. The development of new competencies by employees and the improvement of their qualifications with the help of digital technologies will make it possible to find new solutions in such pressing issues as the exploration and production of hard-to-recover oil, the construction of offshore fields, and the transportation of oil from the Far North.

An analysis of the possibilities of using immersive technologies in personnel training is presented in [2630].

In [31], the author rightly believes that virtual or augmented reality is capable of making revolutionary changes not only in the technology of hydrocarbon production. For example, the technology of the so-called "seamless data transfer" will allow any employee to have access to expert advice while working.

Currently, immersive technologies are being introduced into almost all business processes and are becoming an important component, including the HR sphere. Such technologies increase labor productivity and optimize work processes in companies. VR technology within the framework of immersive learning has a significant list of advantages over traditional methods: [28, 32] main advantages:

1. Staff involvement. Unlike the traditional approach, immersive learning tools allow you to train specifically and point-wise. The boundaries between theory and practice are blurring. The bottom line is that the skills you need are learned faster and better.

2. A realistic environment is created that is as close as possible to the real one. With the help of VR, the user works out his interaction with objects and other people in real time. The technology makes it possible to most fully simulate situations that a user can get into, program several scenarios for the development of events, and play various scenarios.

3. Reduced operating costs. Working time is used efficiently: training is carried out when it is convenient for all parties, and not when access to the installation / facility becomes available. Any operations can be repeated without restrictions until the necessary skill is mastered.

4. Learning through experience and mistakes. The student has the opportunity to make mistakes and see the results of his actions, while neither himself nor the attitude is damaged.
5. Better analysis of results. Immersive learning collects a variety of user data - behavior, eye tracking, heat maps, and gesture tracking. Management can analyze learning experiences and test results using automatic reports embedded in the training software.

The use of immersive technologies in personnel training will allow you to go through the training path without loss and without danger to the life of each individual employee.

\section{Results}

Virtual reality (VR) technologies are a $3 \mathrm{D}$ environment created by a computer that a person can interact with using special devices. This technology fully conveys visual and audio information content, evokes emotions and makes it possible to gain practical experience in situations close to real ones, which is very important when training personnel of oil and gas companies in remote Arctic territories. Unlike VR, augmented reality (AR) technologies do not create a full-fledged threedimensional space, but only superimpose elements of virtual reality on the image of the real world. Thus, combining the real and the virtual makes it possible to obtain a unique user experience without immersion in the digital environment. In mixed reality (MR) technologies, virtual objects are "drawn" to the present, forming a synthesis of the digital and real world. Based on this, it can be argued that mixed reality is a combination of augmented and virtual reality.

Thus, the use of VR / AR / MR technology allows reengineering of existing business processes for oil and gas enterprises and transforming the value chain into digital form.

The leading trends in the use of VR / MR / AR technologies in the oil and gas complex are [33]:

Conducting training programs. Oil and gas education is one of the main areas where virtual reality has become widespread. VR technology allows you to create 3D walkthroughs in real-world locations, including oil and gas assets. It assists in delivering training programs using immersive 3D models to help improve understanding of various systems and processes used in industry.

Simulation of oil and gas operations. VR provides the user with an immersive experience when it creates 3D simulations of real-world environments. Simulation of real-world scenarios provides data on important parameters of oil and gas operations, which can be useful for preliminary assessment of the effectiveness of various processes. VR allows companies to create a digital twin to replicate the performance of an oil field, refinery, or any other operating unit on a virtual platform. This helps to minimize the risks and costs associated with implementing a new process in oil and gas operations.

Analysis of the surface of oil fields. VR plays an important role in the creation of $3 \mathrm{D}$ images of underground geological structures. VR can simulate underground reservoirs, structural faults and other geological formations to create $3 \mathrm{D}$ digital models. This 
technology helps geologists, geophysicists and engineers better understand topography to identify potential hydrocarbon reserves and accurately plan drilling operations.

Testing and verification of processes. VR is used to improve the efficiency of inspection and maintenance through data-driven modeling. This technology helps integrate historical data with real-time information to identify service requirements and guide technicians to the tasks that must be completed to prevent impending disruption. This includes step-by-step instructions for finding the defective part and repairing or replacing it, which minimizes the time required for maintenance work.

Product design and manufacturing. VR offers new opportunities in product development. Digital designs that are modeled with $3 \mathrm{D}$ rendering are checked for results even before they reach the production stage. VR integrated with $3 \mathrm{D}$ printing can develop multiple prototypes at fast speed. VR technology reduces lead times for critical oil and gas equipment development by accelerating the product design process.

Disaster management using virtual reality. Field technicians in the oil and gas industry operate in harsh environments and are exposed to hazardous gases and chemicals. VR has the potential to train employees in emergency response by simulating real-world scenarios.

A digital twin with VR. Connected devices and the Internet of Things (IoT) are transforming oil and gas operations across the value chain. Companies are connecting sensors to equipment and infrastructure to gather as much data as possible about plant performance to improve visibility and decision making. The digital twin is one such use case for the IoT that allows companies to visualize an enterprise in an immersive environment using virtual reality. It reproduces production processes in a virtual world and helps to identify potential problem areas and develop plans to overcome them.

It should be noted that currently, few companies use immersive technologies due to their high cost or complexity. Nevertheless, these technologies will become increasingly cheaper, which means that in the coming years they will also conquer the oil and gas market.

But, as the analysis performed [17-25] has shown, today a number of oil and gas companies are actively using the following VR technologies in their work:

- Design, analysis of geological exploration data, data accounting in the development of an oil and gas field. 3D visualization of an object allows you to accurately visualize an array of information. Collective projection centers of virtual reality are engaged in its development.

- 3D seismic increases the likelihood of drilling for oil, thereby reducing the risk of dry drilling. The cost of equipment and 3D-modeling pays off after drilling one or two wells at the location suggested by the system.

- For such reconnaissance tasks as photogrammetry and remote sensing of the earth, 3D stereovisualization is actively used. The method enables employees from different departments to quickly assimilate a large amount of information about the field, conduct analysis and make the best decision, while reducing the likelihood of error.

- Interactive devices for displaying 3D models, the use of technology in video conferencing allow to combine the efforts of specialists of different levels at the same time. And 3D presentations with an effective and understandable three-dimensional picture are clear and intuitive even for non-specialists, potential shareholders and investors.

Only a few of the Russian companies have already begun to actively rebuild production and business processes in order to gradually carry out a complete digital transformation. There are 27 smart fields operating in the country, the largest vertically integrated oil companies are developing their own technological strategies.

For the first time in its history, PJSC LUKOIL has applied digital technologies in production. The test site was the Kokuyskoye field in the Perm region. The system monitors the production process and the operation of pumping equipment. PJSC "Surgutneftegas" has significantly reduced costs by implementing the InMemory application system in the company, which helps to keep automated accounting of products, calculate prices, and promptly provide employees with important information. In 2017, PJSC Gazpromneft-Khantos opened a MCC - a production control center. At the heart of the MCC is the "Digital Twin" complex, which trains itself. The program selects the optimal operating mode of the equipment, predicts emergency situations and proposes measures to prevent them.

Based on the analysis of the use of immersive technologies by Russian enterprises, as well as taking into account the industry specificity of oil and gas enterprises, it is possible to propose the main directions for using VR / AR / MR technologies in training personnel at oil and gas enterprises (Table 1).

Table 1. Directions of using immersive technologies in training personnel at oil and gas enterprises

\begin{tabular}{|c|c|c|c|c|c|c|c|c|}
\hline $\begin{array}{l}\text { Directions of use } \\
\text { immersive } \\
\text { technologies }\end{array}$ & 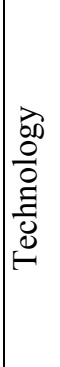 & 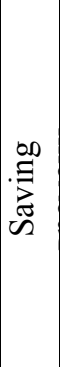 & $\stackrel{\stackrel{\oplus}{\Xi}}{\circlearrowright}$ & 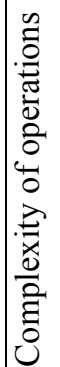 & 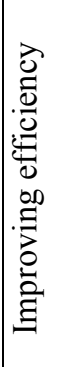 & 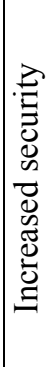 & 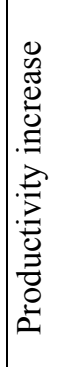 & 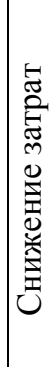 \\
\hline $\begin{array}{l}\text { Trainings on } \\
\text { assembly / } \\
\text { disassembly, repair } \\
\text { and maintenance of } \\
\text { equipment }\end{array}$ & VR & & & & ++ & ++ & ++ & \\
\hline $\begin{array}{l}\text { Trainings for } \\
\text { practicing measures } \\
\text { to prevent terrorist } \\
\text { threats at the } \\
\text { enterprise, on }\end{array}$ & VR & ++ & $\begin{array}{l}++ \\
+\end{array}$ & + & ++ & $\begin{array}{l}++ \\
+ \\
+\end{array}$ & ++ & $\begin{array}{l}++ \\
+\end{array}$ \\
\hline
\end{tabular}




\begin{tabular}{|c|c|c|c|c|c|c|c|c|}
\hline $\begin{array}{l}\text { behavior in extreme } \\
\text { situations and } \\
\text { liquidation of } \\
\text { accidents } \\
\text { Conducting training } \\
\text { for employees in } \\
\text { order to master new } \\
\text { digital and other } \\
\text { competencies } \\
\end{array}$ & & & & & & & & \\
\hline $\begin{array}{l}\text { Conducting training } \\
\text { for employees in } \\
\text { order to master new } \\
\text { digital and other } \\
\text { competencies }\end{array}$ & AR & +7 & 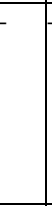 & + & ++ & + & ++ & \\
\hline $\begin{array}{l}\text { Overlay real-time } \\
\text { data on real machine } \\
\text { parts }\end{array}$ & AR & & & & ++ & ++ & ++ & \\
\hline $\begin{array}{l}\text { Comparison of } \\
\text { physical and virtual } \\
\text { hardware versions }\end{array}$ & AR & & ++ & & ++ & & & ++ \\
\hline $\begin{array}{l}\text { View help videos and } \\
\text { digital tutorials. } \\
\text { Visualization of } \\
\text { historical } \\
\text { maintenance records } \\
\text { and presentation of } \\
\text { task } \\
\text { recommendations } \\
\end{array}$ & $\mathrm{AR}$ & & $\begin{array}{ll}++ \\
+\end{array}$ & & ++ & ++ & ++ & ++ \\
\hline \begin{tabular}{|l} 
Visualization of the \\
infrastructure project \\
from different \\
perspectives \\
Visualization of \\
specific components \\
and functions beyond \\
the physical \\
boundaries of the \\
equipment
\end{tabular} & AR & & & ++ & ++ & ++ & ++ & \\
\hline $\begin{array}{l}\text { Visualization of the } \\
\text { "digital twin" to } \\
\text { simulate a real } \\
\text { environment }\end{array}$ & $\left|\begin{array}{c}\mathrm{VR} \\
1 \\
\mathrm{AR}\end{array}\right|$ & & & & ++ & + & ++ & \\
\hline $\begin{array}{l}\text { Preliminary design } \\
\text { concept entirely } \\
\text { created in VR }\end{array}$ & VR & & & & ++ & ++ & ++ & ++ \\
\hline $\begin{array}{l}\text { Remote interaction } \\
\text { between different } \\
\text { locations in order to } \\
\text { view the same design } \\
\text { data and resolve } \\
\text { conflict situations } \\
\end{array}$ & $\begin{array}{c}\mathrm{VR} \\
1 \\
\mathrm{AR}\end{array} \mid$ & & & & ++ & & ++ & $\begin{array}{l}++ \\
+\end{array}$ \\
\hline $\begin{array}{l}\text { Virtual inspection of } \\
\text { the production site }\end{array}$ & VR & & & & ++ & ++ & ++ & + \\
\hline $\begin{array}{l}\text { Conducting training } \\
\text { activities on labor } \\
\text { protection in order to } \\
\text { develop skills to } \\
\text { prevent emergency } \\
\text { situations }\end{array}$ & VR & & & ++ & & $\begin{array}{l}++ \\
+\end{array}$ & & \\
\hline $\begin{array}{l}\text { Introducing new } \\
\text { employees to the }\end{array}$ & VR & & ++ & ++ & ++ & $\begin{array}{l}++ \\
+\end{array}$ & + & + \\
\hline
\end{tabular}

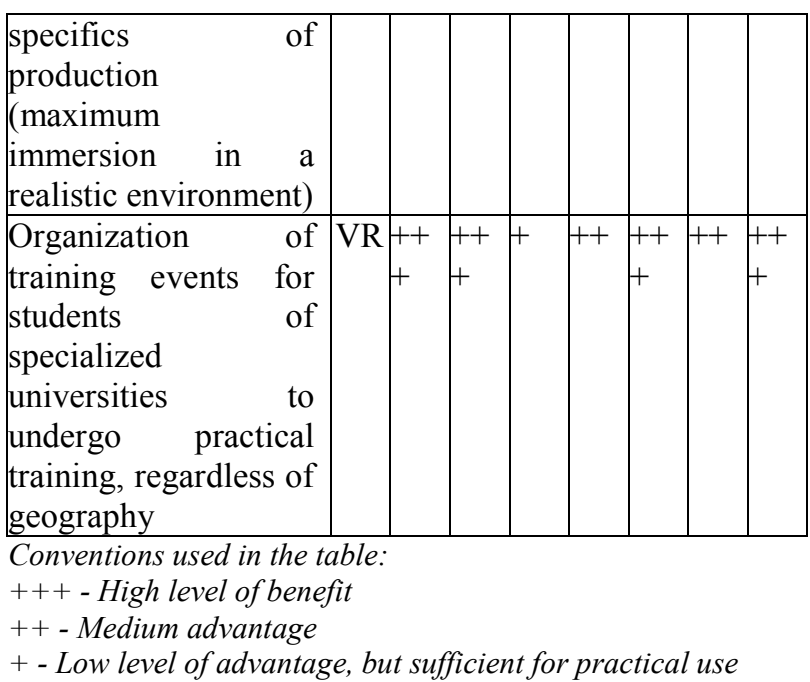

The analysis carried out confirms the idea that was expressed: immersive technologies in personnel training were obtained for the following categories of workers [34].

1. Workers involved in any mechanical operation. Immersion learning is more successful in cases that require first-person presentation, interactive practice, and tactile feedback from the operations performed.

2. Employees whose work requires a high level of communication skills as well as empathy. Training on such simulators allows you to play the situation of emotional impact in advance and prepare the employee for a calm response to a potential client. This reduces the number of conflicts in the workplace, and also contributes to a more persistent emotional state of the employee.

3. Employees whose activities are associated with a constant threat of dangerous situations. The use of immersive learning using VR allows you to replay emergencies at the training stage without any material loss.

Personnel training using VR technologies is based on the "immersion" of the employee in a realistic working environment in which he needs to perform certain tasks. At the same time [35], four types of immersion can be distinguished: sensory, spatial, psychological and emotional. Based on this, it can be assumed that the effectiveness of training on VR simulators is due to the simulation of real situations in a digital environment, experiencing which a person experiences the same emotions and sensations as in real life.

Quite often, for the development of these specific components of VR / AR solutions - content and scenarios - integrator companies outsource highly specialized specialists - graphic designers and programmers. At present, it may be economically unprofitable to have such specialists on the permanent staff of integrator companies, since ongoing projects do not yet generate a steady stream of needs from customers. The cost of projects depends on the type of project and the planned use of the VR / AR solution on an industrial scale.

The cost of scaling a project to an industrial level depends on the specifics of the solution itself and the 
deployment model. If industrial implementation involves an increase in the volume of VR / AR / MR applications content (an increase in the number of scenarios, complication of scenarios and visual models, etc.), then the cost of industrial implementation will increase in proportion to the number of these specific developments.

The unconditional benefit from the use of immersive technologies in personnel training at oil and gas enterprises will improve various technological processes. In the oil and gas industry, there are several possibilities for applying virtual reality technology:

1. To minimize the costs of payroll by conducting practical training for company personnel with minimal involvement of a trainer. It will allow you to increase the rate of training of company employees, both new and existing ones.

2. It will allow, without loss of time and information, to carry out the so-called seamless transition of the employee to the work environment from the built environment.

3. From the first minutes of work in the company, the employee is involved through simulation in the real working environment of the company.

4. The student worker immediately joins the work, that is, he is, in fact, an active participant, which will help him in the future at work in the "field conditions".

5. Allows to reduce the cost of personnel training. A large number of employees can be trained at one virtual station during a month. The cost of training will be cheaper than practical training. Workouts can be completed several times.

6. The possibility of multiple trainings will increase the efficiency of the personnel by immersing in the work situation when problems arise.

7. Training with the help of VR technologies will help avoid different interpretations of understanding of corporate standards and values in the company. This is possible because training throughout the geography of the company is carried out according to uniform corporate standards and requirements.

Virtual reality centers are flexible systems that, depending on the configuration, can adapt to different functional requirements of companies, room sizes and other conditions.

However, despite the wide functionality and prospects of using virtual reality technologies in teaching, VR technologies have a number of disadvantages [36, 37]:

1. Virtual reality technologies are still associated with the gameplay, so students treat learning as a game not seriously.

2. VR is perceived differently by men and women, which is explained by the difference in the perception of the world.

3. Not all students have the same level of digital skills, which can cause discomfort for the training participants. What's more, VR requires significant graphics power that conventional computers may not be able to handle.

Unfortunately, the listed disadvantages of using virtual / augmented reality technologies hinder their widespread use and use in training personnel at industrial enterprises.

\section{Conclusion}

Immersive technologies are an effective tool for training employees and developing their soft-skills and hardskills. This is confirmed by a number of successful foreign and domestic practices of using virtual reality for educational purposes. VR simulators and simulations make it possible to increase employee involvement in the training process, reduce training costs, scale educational programs, etc. At the moment, not all Russian companies are ready to implement virtual reality technologies in employee training, for which there are a number of reasons, among which it is worth noting the following: insufficient level of digitalization of the enterprise, unpreparedness for large investments, and insufficient awareness of modern technologies. However, immersive technologies continue to evolve and become more and more accessible, which may lead to the digitalization of corporate education in general, and the wider use of MR / VR / AR technologies in personnel training in particular.

VR / AR technologies can be used by both highly professional specialists and workers. With the use of augmented reality, it will be possible to instantly receive diagrams and electronic instructions for the equipment of oil facilities, to warn of possible breakdowns without the need to use paper-based documentation. The employee can get acquainted with the video information displayed as a supplement to reality, graphic or textual information, to a certain physical object. These can be step-by-step instructions for repair, fixing indicators and characteristics of oil equipment, a description of its purpose. In addition, using augmented reality, you can determine at what stage the task is completed, receive data online, without interrupting the workflow.

At the moment, augmented and virtual reality technologies are widely used in the media and entertainment industry, and are gradually being introduced into the field of corporate education. According to the Modern Media Research Institute (MOMRI), presented in the industry report "The Russian Virtual Reality Market 2016", 28\% of VR projects for business belong to the Education and Training category, which is the leader in the B2B VR market. [38]. This indicates that high-tech public and private companies are using virtual reality technology to train their staff.

\section{References}

1. Monitoring the quality of training. Russian Federation. Available online: http://indicators.miccedu.ru/monitoring/?m=spo/ (2020)

2. HCL Technologies. Bringing digital to life. Available online: https://www.softwareag.com/ru/images/Bringing $\% 2$ 0Digital $\% 20$ to $\% 20$ Life $\% 20$ - 
\%20Global\%20Survey_HCL\%20Technologies tcm 404-165566.pdf/ (2020)

3. R. Morakanyane, Conceptualizing Digital Transformation in Business Organizations: A Systematic Review of Literature, Connecting Things to Transforming Our Lives, 427-444 (2017)

4. The 2017 State of Digital Transformation. Available online: https:/www.prophet.com/wpcontent/uploads/2018/04/Altimeter-_-2017-State-ofDT.pdf/ (2020)

5. How to Win at Digital Transformation. Available online:

https://images.forbes.com/forbesinsights/hds_digital _maturity/HowToWinAtDigitalTransformation.pdf/ (2020)

6. What is digital transformation? Available online: http://www.theguardian.com/media-network/medianetworkblog/2013/nov/21/digital-transformation/ (2020)

7. Digital economy Global changes based on new digital technologies and innovative business models. Available online: http://www.fidp.ru/research/digital/ (2020)

8. L. Hrustek, M. Tomicic Furjan and I. Pihir, Influence of Digital Transformation Drivers on Business Model creation. 2019 42nd International Convention on Information and Communication Technology, Electronics and Microelectronics (MIPRO), doi: 10.23919 / mipro.2019.8756666 (2019)

9. Ilyin I.V., Levina A.I., Dubgorn A.S. Digital transformation as a factor in the formation of architecture and IT architecture of an enterprise // Scientific journal NRU ITMO. Series Economics and Environmental Management. 2019. No. 3. URL:

https://www.elibrary.ru/download/elibrary_4118893 4 87754037.pdf/ (date accessed: July 16, 2020).

10. Skripnuk, D. Analysis of the regional modernization processes in a global context with an example of the Russian northern regions International Journal of Systems Assurance Engineering and Management. 2020.11, RR. 100-110.

11. O. Shestak, O.L. Shcheka, Y. Klochkov, Methodological aspects of use of countries experience in determining the directions of the strategic development of the Russian Federation arctic regions, International Journal of Systems Assurance Engineering and Management 11, RR. 44-62 (2020)

12. I.N. Guzov, N.A. Polyakov, V.O. Titov, A.E. Vashchuk, Conditions for the Russian Federation Arctic zone innovative development, E3S Web of Conferences 161, 01027 (2020)

13. V.A. Tsukerman, A.A. Kozlov, Innovative Development Management of Mining Industrial Companies in the Russian Arctic Zone, IOP Conference Series: Materials Science and Engineering 753(6), 062020 (2020)
14. M.L. Belonozhko, S.M. Kirichuk and A.N. Silin, Socio-economic aspects of the development of energy companies in the Arctic region, International Journal of Energy Economics and Policy 9(6), RR, 318-325 (2019)

15. O.Y. Krasulina, Problems of entrepreneurship development in the Russian Arctic Zone, IOP Conference Series: Earth and Environmental Science 180(1), 012019 (2018)

16. S. Tabata and T. Tabata, Economic development of the arctic regions of Russia. Russia's Far North: The Contested Energy Frontier, RR, 11-26 (2018)

17. Consolidated financial statements of Rosneft. Available online: https://www.rosneft.ru/upload/site1/document_cons report/Rosneft_FS_12m2018_ENG.pdfm/ (2020)

18. Energy Saving and Energy Efficiency. Available online: https://www.gazprom-neft.ru/social/energyefficiency/ (2020)

19. Equipment based on high-temperature superconductivity. Available online: https://www.fskees.ru/innovation/intelligent_network/new types_of power_equipment of substations and overhead_p ower_lines/hardware based_high (2020)

20. GAZPROM PJSC Policy in the Field of Energy Efficiency and Energy Saving. Available online: https:/www.gazprom.ru/f/posts/60/091228/ 201811-20-energetic-policy.pdf / (2020)

21. Innovation. Available online: http://ritek.lukoil.ru/ru/Activities/Innovation/ (2019)

22. Innovative strategy of Tatneft Group. Available online:

https://www.tatneft.ru/biznes/innovatsii/innovatsion naya-strategiya-gruppi-tatneft/?lang $=\mathrm{ru} /$ (2020)

23. Integrated Report 2018. Available online: https://ar2018.suek.com/en\#company/ (2020)

24. JSC Concern Rosenergoatom. Available online: https://www.rosenergoatom.ru/ (2020)

25. JSC Inter RAO-Electric Power Plants. Available online: http://irao-generation.ru/information/ (2020)

26. Teaching Methodology for Virtual Reality Practical Course in Engineering Education. Available online: https://www.sciencedirect.com/science/article/pii/S1 $\underline{877050913012362}$ (2020)

27. Augmented Versus Virtual Reality in Education: An Exploratory Study Examining Science Knowledge Retention When Using Augmented Reality. Available online: https://www.ncbi.nlm.nih.gov/pubmed/30657334 (2020)

28. 4 reasons you need to start using Virtual reality for Learning \& Training. Available online: https://trainingindustry.com/articles/learningtechnologies/4-reasons-you-need-to-start-usingvirtual-reality -for-learning-and-training (2020)

29. Comparing immersive virtual reality and powerpoint as methods for delivering safety training: Impacts on 
risk perception, learning, and de-cision making. Available online: https://www.researchgate.net/publication/32653533 7 Comparing Immersive Virtual Reality and Po werPoint as Methods forward_Delivering_Sapping (2020)

30. Case Study - The Impact of VR on Academic Performance. Available online: https://docplayer.net/30723457-A-case-study-theimpact-of-vr-on-academic-performance.html (2020)

31. V. Ryzhonkov, 2017 for virtual and augmented reality: how technologies will come to the mass market. Available online: http://www.forbes.ru/tehnologii/340601-2017-ygod-dlya-virtualnoy-i-dopolnennoy/ (2020)

32. A. Smirnova, I. Zaychenko and I. Bagaeva, Formation of requirements for human resources in the conditions of digital transformation of business, Proceedings of the International Conference on Digital Technologies in Logistics and Infrastructure (ICDTLI 2019). Available online: https://www.atlantis-press.com/proceedings/icdtli19/125918521/ (2019)

33. Portal Pro-Arktic. Available online: https://proarctic.ru/27/12/2019/news/38726/ (2020)

34. Comparing immersive virtual reality and powerpoint as methods for delivering safety training: Impacts on risk perception, learning, and de-cision making. Available online: https://www.researchgate.net/publication/32653533 7 Comparing_Immersive Virtual Reality and Po werPoint as Methods forward Delivering (2020)

35. V. M. Dozortsev, Virtual reality technology in training operators of technological processes, Automation in industry 6, $42-50$ (2018)

36. D. Velev, Virtual Reality Challenges in Education and Training, International Journal of Learning and Teaching, 1, 33-37 (2017)

37. A. Kozlov, A. Kankovskaya, A. Teslya, Z. Khasheva, Motivating factors for university students to use digital technologies in educational process, Proceedings of the International Conference on Digital Technologies in Logistics and Infrastructure (ICDTLI 2019). Available online: https:/www.atlantis-press.com/proceedings/icdtli19/125918490/ (2020)

38. Virtual reality market in Russia 2016 Available online: http://files.rtrends.ru/reports/MOMRI. VR market_in_Russia. April_2017_rus.pdf/ (2020) 